\title{
RANCANG BANGUN SISTEM KONTROL OTOMASI FERTIGASI PARAMETER SUHU SISTEM AEROPONIK PADA CAISIM
}

\author{
1,Alimuddin*), ${ }^{2}$ Ria Arafiyah, ,3Kartina, ${ }^{4}$ Bagus Kukuh Udiarto, 5Suparlan, ${ }^{6}$ Yanto Surdiyanto, ${ }^{1}$ Raden Vergiansayah \\ ${ }_{1}^{1}$ Departemen Teknik Elektro Fakultas Teknik Universitas Sultan Ageng Tirtayasa, Banten \\ 2Program Studi Sistem Komputer Fakultas MIPA Universitas Negeri Jakarta, Jakarta \\ ${ }^{3}$ Departemen Agroekoteknologi Fakultas Pertanian Universitas Sultan Ageng Tirtayasa, Banten \\ 4BALITSA BALITBANG Kementerian Pertanian, Bandung, Jawab Barat \\ ${ }^{5}$ BB MEKTAN BALITBANG Kementerian Pertanian, Serpong, Banten \\ 6BPTP Bandung, Jawab Barat
}

(cooresponding author) E-mail alimuddineeuntirta@yahoo.com*)

\begin{abstract}
Abstrak
Aeroponik merupakan suatu cara bercocok tanam diudara tanpa penggunaan tanah cocok daerah perkotaan. Tanaman yang digunakan adalah tanaman sawi (caisim) merupakan tanaman sayuran kebutuhan pokok masyarakat indonesia. Suhu tanaman merupakan parameter utama yang mempengaruhi jumlah air dan nutrisi yang dibutuhkan sesuai dengan karakteristik tanaman yang ditanam. Penelitian ini bertujuan untuk mengendalikan suhu pada sistem aeroponik sesuai dengan karakteristik tanaman dengan metode pengendalian menggunakan kontrol otomasi pada parameter suhu tertentu. Sistem kontrol secara realtime menggunakan komputer, mikrokontroller Arduino UNO, sensor suhu DHT1, aktuator pompa dan kipas angin. Hasil pengendalian otomatis mampu mengendalikan suhu pada sistem aeroponik dengan tanaman caisim yang berumur kurang lebih 1 bulan dengan keadaan suhu ruangan $30^{\circ} \mathrm{C}$ dan dengan setpoint suhu $28^{\circ} \mathrm{C}$ yang merupakan parameter karakteristik dari tanaman sawi (Caisim) yang ditanam, respon kendali menghasilkan Td 128 detik, Tr 256 detik,Tp 263 detik, Ts 250 detik, Mp 3,57\%, Ess 3,57\%.
\end{abstract}

Kata kunci : sistem kontrol otomasi, suhu, aeroponik, caisim

\section{Pendahuluan}

Pentingnya sayuran bagi kesehatan memicu peningkatan produk sayuran. Untuk menghasilkan sayuran segar, sehat dan bermutu tinggi, diperlukan penanganan yang baik mulai tahap pemilihan lokasi, benih, hingga cara pemupukannya [1]. Sawi merupakan jenis sayur yang digemari oleh masyarakat Indonesia. Dari berbagai jenis sawi, pakcoy termasuk jenis yang banyak dibudidayakan petani saat ini. Kelebihan lain sawi pakcoy yaitu mampu tumbuh baik di dataran rendah maupun dataran tinggi. Tanaman sawi diduga berasal dari Tiongkok (Cina), tanaman ini telah dibudidayakan sejak 2500 tahun lalu, kemudian menyebar luas ke Filipina dan Taiwan serta ke negara- negara Asia lainnya [2].

Aeroponik merupakan suatu cara bercocok tanam sayuran diudara tanpa penggunaan tanah. Akar tanaman yang ditanam menggantung akan menyerap larutan hara tersebut. Air dan nutrisi disemprotkan menggunakan fertigasi sprinkler. Dengan sistem ini maka penanaman dapat dilakukan dimana saja, walaupun dengan investasi awal yang cukup besar.(Susilo DA,2006)

Perbedaan sistem hidroponik dengan sistem aeroponik ada pada cara fertigasinya. Jika pada hidroponik sistem fertigasinya dilakukan dengan cara mengalirkan atau meneteskan nutrisi. Sedangkan pada aeroponik sistem fertigasinya dengan cara menyemprotkan atau menspray nutrisi ke akar tanaman. Dengan perbedaan ini maka dapat dilakukan penelitian sistem fertigasi yang membedakan antara sistem hidroponik dengan sistem aeroponik melalui parameterparameter yang ada pada tanaman.[3,4]

Suhu suatu tanaman merupakan parameter utama yang mempengaruhi jumlah air nutrisi yang dibutuhkan, sehingga dapat melakukan efisiensi pada listrik yang dipakai karena waktu fertigasi yang sudah di kontrol. Dengan melihat beberapa aspek parameter seperti suhu udara, kelembaban, kecepatan angin, durasi fertigasi, interval fertigasi, dan umur tanaman, maka dapat dirancang sebuah sistem kontrol fertigasi ini. Dalam penelitian hanya menggunakan parameter suhu. Sistem aeroponik ini dapat beroperasi untuk tanaman yang berumur 4 minggu, dengan set suhu $26^{\circ} \mathrm{C}$ sampai $30^{\circ} \mathrm{C}$ dan set kelembaban antara $40 \%$ sampai $70 \%$ serta interval penyemprotan air nutrisi berlangsung selama 30 detik.

Mikrokontroler Arduino adalah sebuah board mikrokontroler yang didasarkan pada IC Atmega328. Salah satu contoh yang akan dibahas kali ini yaitu arduino Uno. Arduino UNO mempunyai 14 pin digital input/output (6 di antaranya dapat digunakan sebagai output PWM), 6 input analog, sebuah osilator Kristal $16 \mathrm{MHz}$, sebuah koneksi USB, sebuah power jack, sebuah ICSP header, dan sebuat tombol reset. Arduino UNO memuat semua yang dibutuhkan untuk menunjang mikrokontroler, mudah menghubungkannya ke sebuah computer dengan sebuah kabel USB atau mensuplainya dengan sebuah adaptor AC ke DC atau menggunakan baterai untuk memulainya. $[5,6]$

Sistem, pengaturan dan otomatis. Sistem adalah sebuah susunan komponen-komponen 
fisik yang saling terhubung dan membentuk satu kesatuan untuk melakukan aksi tertentu dengan mengatur, mengednalikan, mengarahkan dan memerintah dengan bekerja sendiri $[7,8]$

Pada penelitian sebelumnya dengan sistem aeroponik ini mampu beroperasi pada bayam yang berumur 4 minggu dengan suhu $30^{\circ} \mathrm{C}$ dan interval penyemprotan selama 30 detik, dengan rata-rata penurunan suhu $0,3^{\circ} \mathrm{C}-0,7^{\circ} \mathrm{C}$ ketika sistem berlangsung serta belum menggunakan mikrokontroler ardino sehingga relative ruwet dibandingkan menggunakan mikrokontroler ardino $[9,10]$. Tujuan penelitian merancang dan membuat sistem kontrol fertigasi otomasi pada parameter temperatur tanaman sawi dengan sistem aeroponik.

\section{Metode Penelitian}

Rancang bangun sistem kontrol fertigasi parameter temperatur dan kelembaban tanaman pada sistem aeroponik ini menggunakan sebuah mikrokontroller Arduino UNO dan sebuah sensor suhu dan kelembaban telah dilakukan serangkaian kegiatan untuk menyelesaikan penelitian ini.

Metodologi yang digunakan untuk penelitian ini adalah pertama, Mempelajari studi tentang sistem aeroponik untuk mengetahui sejauh mana cara bercocok tanam dengan cara sistem aeroponik ini dilakukan, kedua,merancang perangkat keras (Hardware) berupa box aeroponik dan seperangkatnya yang terdiri dari box penampungan air, meja dudukan, tempat dudukan lampu, serta Styrofoam yang digunakan untuk menempatkan tanaman pada netpot, ketiga, merancang rangkaian catu daya 5VDC dan 12 VDC sebagai tegangan input ke mikrokontroller Arduino UNO dan sebagai tegangan input pada kipas atau fan, keempat,Merancang sistem mikrokontroller Arduino UNO sebagai pengontrol temperatur dan kelembaban, kelima, merancang rangkaian sensor DHT11 sebagai pembaca temperatur dan kelembaban yang mempunyai peran yang cukup penting pada penelitian ini, keenam, Merancang penampil LCD (Liquid Crystal Display) berukuran 16x2 sebagai output tampilan yang akan menampilkan temperatur dan kelembaban dari pembacaan sensor temperatur dan kelembaban DHT11 yang sudah diintegrasikan dengan mikrokontroller Arduino UNO, ketujuh, merancang rangkaian relay yang berfungsi sebagai saklar atau switching untuk menghidupkan pompa aquarium dengan menghidupkan kipas atau fan dari parameter temperatur dan kelembaban yang sudah di tentukan melalui pengontrol mikrokontroller Arduino UNO, kedelapan, Merancang program pengontrol pada mikrokontroller Arduino UNO yang akan dihubungkan dengan sensor temperatur dan kelembaban DHT11, Kesembilan,Menguji sistem aeroponik agar nantinya pemberian nutrisi dapat tersalurkan dengan baik, kesepuluh, Menguji temperatur dan kelembaban di dalam box aeroponik menggunakan sensor temperatur dan kelembaban DHT11 yang sudah terintegrasi dengan mikrokontroller Arduino UNO, kesebelas membandingkan hasil dari pembacaan sensor temperatur dan kelembaban DHT11 dengan keadaan aslinya, menggunakan termometer ruangan air raksa, dan sebuah termometer digital. sistem kontrol fertigasi otomasi parameter suhu sistem aeroponik skala laboratorium dengan mikrokontroler ardino.

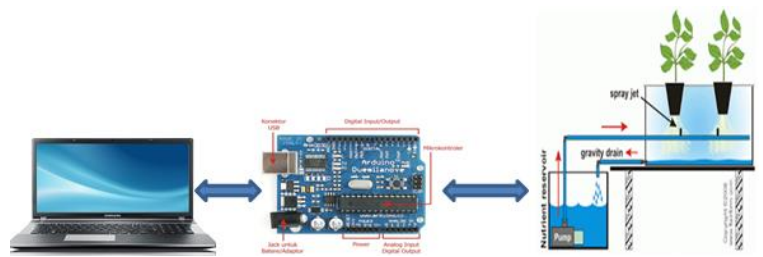
Gambar 1. Integrasi Sistem kontrol otomasi fertigasi aeroponik pada tanaman sawi.

\section{Hasil Dan Pembahasan}

Hasil dan pembahasan ini melakukan pengujian dan pengukurandiantaranya yaitu pengukuran pada saat sensor temperatur mendeteksi ruangan kamar dan sensor temperatur box aeroponik.

Pada saat sensor temperatur mengukur didalam box aeroponik, pada saat itu sudah dikontrol oleh mikrokontroller Arduino UNO. Batasbatas yang digunakan yaitu pada temperatur 25 $30^{\circ} \mathrm{C}$. Ruangan yang digunakan pada penelitian ini adalah ruangan kamar dengan temperatur ruangan $28-30^{\circ} \mathrm{C}$.

Selain itu pengujian terhadap program dari mikrokontroller Arduino UNO untuk menjalankan sesuai fungsinya atau tidak, dengan melakukan monitoring dan kontrol temperatur nutrisi tanaman sawi.

Dalam penelitian ini sensor temperatur yang digunakan adalah sensor DHT11. Pengujian sensor temperatur bertujuan untuk mengetahui sensor dapat berfungsi dengan validasi pada termometer digital. Pengujian pertama dilakukan dalam temperatur ruangan kamar.Pengujian pertama dilakukan dalam temperatur ruangan kamar.

Tabel 1. Pengujian kalibrasi sensor suhu

\begin{tabular}{|l|c|c|}
\hline Pengujian & $\begin{array}{c}\text { Keadaan } \\
\text { Ruangan (C) }\end{array}$ & Temperatur \\
\hline \multirow{2}{*}{ DHT11 } & Pada 28 C & 28,00 \\
\cline { 2 - 3 } & Pada 29 C & 29,00 \\
\hline
\end{tabular}




\begin{tabular}{|c|l|c|} 
& Pada 30 C & 30,00 \\
\hline \multirow{3}{*}{$\begin{array}{c}\text { Termometer } \\
\text { Digital }\end{array}$} & Pada 28 C & 27,8 \\
\cline { 2 - 3 } & Pada 29 C & 28,8 \\
\cline { 2 - 3 } & Pada 30 C & 29,5 \\
\hline
\end{tabular}

Pengujian keseluruhan tersebut, didapat durasi lamanya pompa aquarium mengalirkan nutrisi dan lamanya kipas hidup pada batas-batas temperatur yang sudah di tentukan. Dari hasil pengujian, dapat disimpulkan bahwa sistem bekerja dimana output dari seluruh kondisi dapat bekerja sesuai dengan kondisi yang diinginkan. Dari data tersebut dapat juga terdapat gangguan yang menyebabkan temperatur dan kelembaban sukar dikontrol, yaitu adanya pengaruh dari temperatur dan kelembaban dari luar box aeroponik itu sendiri.

Dari pengujian keseluruhan tersebut, didapat durasi lamanya pompa aquarium mengalirkan nutrisi dan lamanya kipas hidup pada batas-batas temperatur dan kelembaban yang sudah di tentukan.

Dari hasil pengujian sistem dapat dilihat beberapa nilai dari respon kendali sebagai kinerja kendali dengan beberapa kriteria yaitu dapat ditunjukkan pada Tabel 2 untuk suhu.

Tabel 2. Karakteristik tanggapan sistem terhadap perubahan suhu

\begin{tabular}{|c|c|c|c|c|c|c|c|c|}
\hline$\Delta \mathbf{T}$ & $\begin{array}{c}\text { Setpoi } \\
\text { nt } \\
\text { Suhu }\end{array}$ & $\begin{array}{l}\text { Suhu } \\
\text { Awal }\end{array}$ & $\begin{array}{c}\text { Td } \\
\text { (deti } \\
\text { k) } \\
\end{array}$ & $\begin{array}{c}\mathbf{T r} \\
\text { (deti } \\
\text { k) } \\
\end{array}$ & $\begin{array}{l}\text { Tp } \\
\text { (deti } \\
\text { k) } \\
\end{array}$ & $\begin{array}{c}\text { Ts } \\
\text { (deti } \\
\text { k) }\end{array}$ & $\begin{array}{l}\text { Mp } \\
(\%)\end{array}$ & $\begin{array}{l}\text { Ess } \\
(\%)\end{array}$ \\
\hline $1^{\circ} \mathrm{C}$ & $28^{\circ} \mathrm{C}$ & $29^{\circ} \mathrm{C}$ & 88 & 165 & 210 & 248 & $\begin{array}{c}3,0 \\
1\end{array}$ & 3,57 \\
\hline $2^{0} \mathrm{C}$ & $28^{\circ} \mathrm{C}$ & $30^{\circ} \mathrm{C}$ & 126 & 235 & 265 & 299 & $\begin{array}{c}3,0 \\
1\end{array}$ & 3,57 \\
\hline $3^{0} \mathrm{C}$ & $28^{\circ} \mathrm{C}$ & $31^{\circ} \mathrm{C}$ & 184 & 355 & 389 & 410 & $\begin{array}{c}3,0 \\
1\end{array}$ & 3,57 \\
\hline $4^{0} \mathrm{C}$ & $28^{\circ} \mathrm{C}$ & $32^{\circ} \mathrm{C}$ & 211 & 415 & 401 & 499 & $\begin{array}{c}3,0 \\
1\end{array}$ & 3,57 \\
\hline
\end{tabular}

Tabel 2 di atas menghasilkan rata-rata repon kendali Td 152 detik, Tr 292 detik,Tp 316,25 detik, Ts 373 detik, Mp 3,10\%, Ess 3,57 \%.

\section{Kesimpulan}

Adapun kesimpulan adalah : pertama,berhasil merancang bangun sistem control fertigasi siste aeroponik dengan parameter suhu pada tanaman sawi, kedua Hasil pengujian selama 4 minggu dengan suhu setpoin $28^{\circ} \mathrm{C}$ dan suhu ruangan 29 $32^{\circ} \mathrm{C}$ menghasilkan respon kendali yang baik, yaitu respon kendali Td 152 detik, Tr 292 detik,Tp 316,25 detik, Ts 373 detik, Mp 3,10\%, Ess 3,57\%

\section{Ucapan Terima Kasih}

Ucapan terima kasih kepada Kementeria Pertanian Republik Indonesia atas pembiayaan penelitian untuk Skim Hibah KKP3N Litbang
Kementerian Pertanian kepada peneliti 20152016

\section{Daftar Pustaka}

[1] Adiyoga,W.1999, Pola Pertumbuhan Produksi Beberapa Jenis Sayuran di Indonesia

[2] Fahrudin, Fuat. 2009. "Budidaya Caisim Menggunakan Ekstrak Teh Dan Pupuk Kascing". Surakarta: Universitas Sebelas Maret.

[3] Susila, D Anas. 2006. "Panduan Budidaya Tanaman Sayuran",IPB Bogor,

[4] Sumarni, Eni. 2013. "Pendinginan Zona Perakaran (Root Zone Cooling) Pada Produksi Benih Kentang menggunakan Sistem Aeroponik". Bogor: Institut Pertanian Bogor.

[5] Anonim, DFRobot. Digital-Output relative \& temperature sensor/modul - DHT11.

[6] Artanto, Dian. 2012. "Interaksi Arduino dan LabVIEW". Jakarta: Elex Media Komputindo

[7] Ogata, Katsuhiko. 2002. "Modern Control Engineering". University Of Minnesota.

[8] Alimuddin, Ria Arafiyah, Sirajuddin, Adipurna 2013, "Perancangan Sistem Pengendali Model Suhu Pada Closed House Menggunakan Metode Fuzzy Logic Control".Prosiding Seminar Nasional SNTE PNJ, Jakarta

[9] Diansari, Muthia. 2008. "Pengaturan Suhu, Kelembaban, Waktu Pemberian Nutrisi Dan Waktu Pembuangan Air Untuk Pola Cocok Tanam Hidroponik Berbasis Mikrokontroller AVR ATMEGA 8535". Depok: Universitas Indonesia.

[10]Ferdiansyah. 2012. "Rancang Bangun Sistem Kontrol Pada Budidaya Tanaman Dengan Teknik Aeroponik". Surabaya: Institut Teknologi Sepuluh November. 